\section{PAISAJES EXPOSITIVOS. EL RECINTO FERIAL DE LA CASA DE CAMPO DE MADRID José de Coca Leicher}

\author{
Presentación José Manuel Calvo \\ Prólogo Gabriel Ruiz Cabrero y Juan Manuel Fernández Alonso
}

\section{Pedro Moleón Gavilanes}

Madrid: Ediciones Asimétricas, 2018

313 págs., $15 \times 20 \mathrm{~cm}$

ISBN: 978-84-949522-0-3

Este libro de José de Coca tiene una deuda directa con su tesis doctoral, codirigida por los arquitectos y catedráticos José María Mercé Hospital y Javier Ortega Vidal y defendida en 2013 en la Escuela de Arquitectura de Madrid. El libro no es la tesis, pero, hay que decirlo, sin merma del interés del resultado que se publica en esta edición pensada para un público que excede el ámbito académico, ya que ha ganado en intensidad al concentrase y depurarse, aunque se echan en falta notas, y mayor formato, por el valor de las imágenes, especialmente los dibujos del autor, auténticas joyas para el análisis y la comprensión de las arquitecturas feriales.

El libro de José de Coca se articula en dos partes principales, sobre la I Feria Nacional del Campo celebrada en 1950, y sobre las posteriores, ya internacionales, que se realizarán entre 1953 y 1975 . Antes, el autor nos habla del lugar y su entorno, del antecedente de las primeras ferias de la Asociación de Ganaderos celebradas allí en los años 1920 s, en pabellones proyectados por Juan Moya Idígoras, y del contexto de la sociedad, la arquitectura y el urbanismo en el Madrid de los años cuarenta, los preparatorios de la primera feria. "Traer el campo a la ciudad" fue el eslogan entonces, y hay que entenderlo en su sentido político y, si se quiere,
This book by José de Coca has a direct debt with his doctoral thesis, codirected by the architects and university professors José Maria Mercé Hospital and Javier Ortega Vidal and presented in 2013 in the Madrid School of Architecture. The book is not the thesis, but it must be said, without lessening the interest of the results published in this edition and aimed at a public which exceeds the strictly academic scope, it has gained in intensity through focus and refinement. Certainly the annotations and the larger format are missing, but due to the value of the images, especially the author's drawings, it is truly a jewel for the analysis and understanding of exhibition ground architecture.

The book by José de Coca is articulated in two main parts, covering the 1st National Country Fair held in 1950, and then the latter ones, now international, carried out between 1953 and 1975. Before that, the author describes the place and its environment. Of the antecedent of the first fairs of the Association of Cattle Breeders held there in the 20's, in pavilions projected by Juan Moya Idígoras, and in the context of the society, architecture and urban development of Madrid of the 40 's, the preliminaries of the first fair. "Bring the country to the city" was then the slogan, and it should be understood in its political, and if one

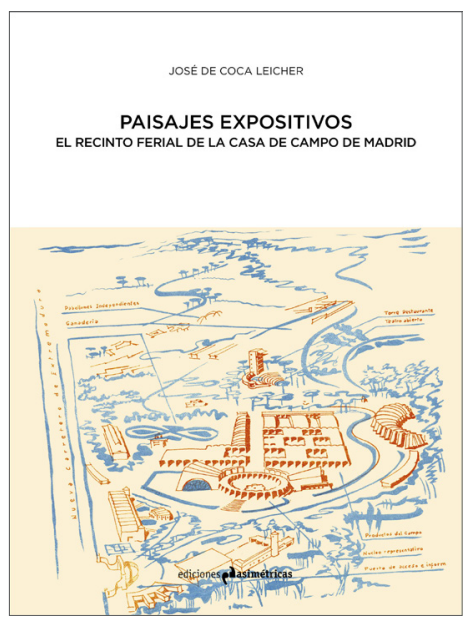

Boletín Académico.

Revista de investigación y arquitectura contemporánea.

Escola Técnica Superior de Arquitectura. Universidade da Coruña

ISSN 0213-3474

eISSN 2173-6723

http://revistas.udc.es/index.php/BAC Número 9 (2019) | Páginas 159-160 DOI: https://doi.org/10.17979/ bac.2019.9.0.5253

Fecha de recepción $\quad 31 / 10 / 2018$

Fecha de aceptación 30/04/2019

Este trabajo está autorizado por una Licencia de Atribución de Bienes

Comunes Creativos (CC) 3.0 


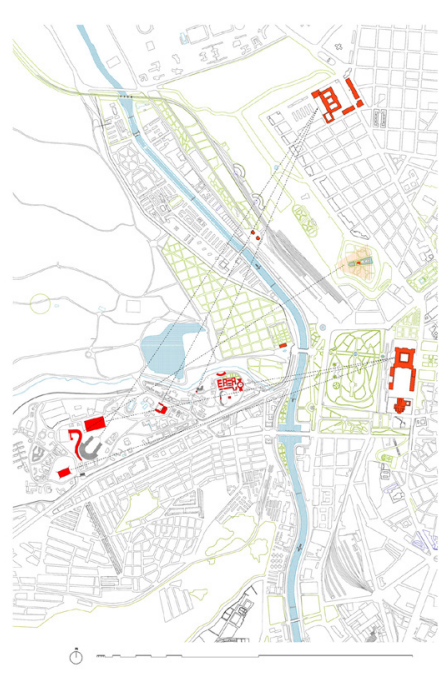

Fig. 01. Imagen de la obra Paisajes Expositivos moral. Es el espíritu de la vida en el campo, con lo que tiene de sacrificio, disciplina y entrega, el que se quiere traer a la metrópoli y ese espíritu resulta inspirador para los arquitectos Asís Cabrero y Jaime Ruiz, que aportan a la arquitectura española edificios de insólita modernidad en los que la razón constructiva, basada en sistemas tradicionales de arcos y bóvedas de ladrillo, es la gran protagonista donde la "inherencia forma-función", como diría Cabrero, produjo espectaculares espacios expositivos.

En 1951 comenzaron las gestiones para ampliar del recinto ferial hacia el oeste, dando continuidad al contenido agrícola y ganadero original incluyendo también el industrial. En las ferias internacionales celebradas cada tres ańos entre 1953 y 1975 participarán junto a Cabrero y Ruiz otros arquitectos españoles en los pabellones de provincias: Zuazo, Fisac, De la Sota, Aburto, Feduchi, Leoz, Romaní y Cavestany, entre otros. El pabellón de los hexágonos de Corrales y Molezún fue trasladado de Bruselas y reconstruido para la Feria del Campo de 1959. Finalmente, el resultado obtenido estaba en relación con un laboratorio de ideas para la integración de las artes, dentro de un sistema de paisajes expositivos, en el que la topografía, la naturaleza y los puntos de vista pintorescos se unen para urbanizar de forma orgánica la periferia de Madrid con un carácter radicalmente moderno que no decae a lo largo de veinticinco años.

Derribos, abandono y usos esporádicos han dejado lo construido en el estado en que se encuentra hoy, necesitado de recuperación, consolidación y reactivación, especialmente ahora que conocemos con hondura su alto valor patrimonial gracias al magnífico libro de José de Coca. wishes, moral sense. It is the spirit of life in the country, which implies sacrifice, discipline and dedication, which is sought to be brought to the metropolis and this spirit proves an inspiration for the architects Asís Cabrero and Jaime Ruiz, providing Spanish architecture with buildings of incredible modernity in which constructive reasoning, based on traditional systems of brick arches and vaults, is the main protagonist where the "form- function inherence", as Cabrero would say, produced spectacular interpretive spaces.

In 1951 official procedures began in order to enlarge the exhibition ground towards the west, giving continuity to the original agricultural and livestock content and also including industrial elements. In the international fairs held every three years between 1953 and 1975 , along with Cabrero and Ruiz, other Spanish architects participated in the provincial pavilions: Zuazo, Fisac, De la Sota, Aburto, Feduchi, Leoz, Romaní y Cavestrany, among others. The hexagonal pavilion of Corrales y Molezún was transported to Brussels and rebuilt for the 1959 Country Fair. Finally, the result obtained was in relation to a laboratory of ideas for the integration of the arts, within a system of interpretive landscapes in which topography, nature and picturesque points of view join to develop Madrid's suburbs organically with a radically modern character that does not decline over twenty five years.

Demolition, neglect and sporadic use have left what has been built in the state In which it finds itself today and needs to be recovered, consolidated and reactivated, especially now that we know in depth its great patrimonial value thanks to the magnificent book by José de Coca. 